九州大学学術情報リポジトリ

Kyushu University Institutional Repository

\title{
THE LOWER CARBONIFEROUS KAKISAKO FORMATION OF SOUTHERN KYUSHU, WITH A DESCRIPTION OF SOME CORALS AND FUSULINIDS
}

Kanmera, Kametoshi

Faculty of Sciences, Kyushu University

https://doi.org/10.5109/1524106

出版情報：九州大學理學部紀要：Series D, Geology. 3 (4), pp.157-178, 1952-12-31. Faculty of Science, Kyushu University バージョン :

権利関係 : 


\title{
THE LOWER CARBONIFEROUS KAKISAKO FORMATION OF SOUTHERN KYUSHU, WITH A DESCRIPTION OF SOME CORALS AND FUSULINIDS
}

\author{
By
}

\author{
Kametoshi Kanmera
}

(Received September 16, 1952)

\section{Introduction}

That the various stages of the Upper Paleozoic are distributed in the mountainous areas of southern Kyushu was firstly suggested by the pioneer work of H. OHTANI (1926). Subsequently H. YABE and T. Sugryama (1939) discovered some Lower Carboniferous corals in a limestone block obtained near a limestone-exposure of Tsutsui, Kakisako-mura, Yatsushiro-gun, Kumamoto Prefecture. In spite of these suggestive previous works a detailed stratigraphic and paleontological study of the Paleozoic in Kyushu seems to have been neglected for some time, whereas that in the southern part of Kitakami massif of northeastern Japan has been progressed in a excellent state. Since 1947 I have been engaged in a systematic research on the Paleozoic formations of southern Kyushu under the guidance of Prof. T. Matsumoto and Assist. Prof. R. Toriyama, and am still carring on the work. The result of the study was partly reported in separate papers (T. MATSUMOTO and K. Kanmera 1949, K. Kanmera 1952) and this note is also one of the results. Here I will report in detail on the Lower Carboniferous formation in Kakisako-mura, on which the previous authors gave only a brief account, and describe some corals and fusulinids among my collection from the same formation. 


\section{General Geological Condition}

A group of strata including the above-mentioned limestone of Tsutsui is distributed in a narrow belt of eastnortheast trend. The belt occupies a fraction in the northern part of Kuriki-mura and Kakisako-mura. It is crossed by valleys of meridional trend, the Mizunashi-dani in its western part, the main valley of the Hikawa in its central part and the upper tributaries of the same valley in its eastern part. It is 800 to 1300 meters in breadth and attains at least $9 \mathrm{~km}$. in length, although its eastern extremity is not accurately investigated. To the Paleozoic strata under consideration I will give here the new name Kakisako-formation.

The belt of the Kakisako formation is in contact with that of the Tobiishi group (Moscovian, Uralian and Sakmarian: K. KANMERA 1952) on its northern side and that of the Kuma group (Upper Permian: T. MATsumoto and K. KANMERA 1949) on its southern side. The boundary is a group of high angled faults along which serpentinite and diabasic rocks are frequently intruded.

The general trend of strata of the Kakisako formation is NEE-SWW, and the dip is generally very high (60-80 degrees) and sometimes vertical. In the midst of the belt there is a nearly upright and closed syncline with a axis parallel to the trend of this belt. These and other features are illustrated in the geologic map and profile.

The strata are intensely deformed and contorted, and their original bedding planes are not always preserved. The dip of strata varies greatly. The strike faults of major and minor scale are frequently found in parallel with the trend of strata. Futhermore, a system of fault in NWW to NS trend is developed with a nearly equal interval. They are mostly vertical or highly angled, and are observable on exposures or proved by tracing of beds.

\section{Stratigraphic Sequence and Rock Facies}

The Kakisako formation is divided into two conformable subformations, the upper and the lower. They are lithologically well distinguished with each other in the type area, but does not 
reveal any remarkable lithlogic difference in other places, as shown in columnar sections and geologic map.

The lower subformation is mostly composed of dark grey to black shale with some lenticular beds of sandstone, intercalates fossil-bearing limestone lentils in its middle part, and is accompanied by a local conglomerate at the horizon 3 to $10 \mathrm{~m}$. above the limestone. Futhermore, chert less than $3 \mathrm{~m}$. thick locally occur at two horizons in the lower part. The lower limit is unexposed owing to faulting. The thickness of the exposed part of the subformation is estimated at about 300 to $350 \mathrm{~m}$.

Shale was originally bedded in thin layers, containing commonly sandy laminae and sometimes thin layers of fine grained sandstone. However, as the strata were intensely folded, shale has been changed to slate. Slate is very fissile, split into thin contorted laminae and in some part provided with pseudoconglomeratic structure which were formed dynamically from detached thin beds and laminae of fine grained sandstone contained in the shale.

Limestone occurs at a limited horizon of the middle part and is found only in the southern wing. It is typically exposed in several tributaries of the northern side of the Hikawa valley from Tsutsui to Kawaiba. Limestone is of lenticular form and varies greatly in thickness, grading laterally into thin bedded calcareous shale and shale within a short distance. Its maximum thickness is $60 \mathrm{~m}$. The lowest part of the limestone lenses is usually white to grey, massive, contains frequently chert in thin layers and small blocky or nodular lenses of irregular form. The main part is black to dark grey in color, bedded in thin to moderately thick layers, sometimes massive, impure and fairly argillaceous in composition, and rather compact and for the most part oolitic in texture. Sometimes it contains irregular thin bands or small lenses of chert. The limestone yields fossil remains of corals and foraminifera. Fossils are very poor in the lower part of limestones, but remains such as Tetracoral are rarely found. The main part of limestones contains fairly commonly foraminifera and sparsely corals. But the assemblage of fossils is similar throughout the whole thickness of limestones.

Sandstone occurs in lenticular form at various horizons, especially common in the middle part, but is generally little in 
amount. It shows rapid thickening and thining out and is not continuous. The sandstone is grey to dark grey in color, wellsorted, mostly medium-grained, and grains of quartz are little in amount, whereas those of feldspar predominate. Sometimes there are very coarse-graind sandstones in which fragments of black shale are found frequently.

Local lenses of conglomerate or conglomeratic sandstone are developed here and there at a constant horizon of the middle part. In the southern wing they lie 3 to $10 \mathrm{~m}$. above the limestone and are found only at the place where limestone is present. Between the conglomerate and the limestone slate is intercalated. In some places conglomerate and conglomeratic sandstone are developed directly above and below the limestone. In the northern wing it occurs at a horizon that correspond approximately to the horizon in the southern wing, is accompanied small limestone lenses or patches in some part.

The conglomerate is of lenticular form, variable in thickness, usually 1 to $2 \mathrm{~m}$., and $7 \mathrm{~m}$. in the maximum thickness, but thins out into slate for a short distance. It is ill-sorted, consisting usually of subangular granules and pebbles, sometimes cobbles, passes rapidly to pebbly sandstone or coarse-grained sandstone. The components of pebbles and cobbles are those of aplite, quartz-porphyry, porphyrite, quartzite, sandstone and shale. The matrix is sandy.

In the strata other than the limestone no fossils have been discovered.

The upper subformation consists of dark grey to black shale, with lenses of sandstone, in the western and eastern parts of the mapped area, but it is composed mostly of basic pyroclastic rocks, lavas and chert, and occasionarlly intercalates grey shale, in the middle part from Uchikoshi to Miyama and Koba. The thickness of this subformation is about 200 to $250 \mathrm{~m}$.

Shale is changed dynamically to slate like that of the lower subformation.

Pyroclastic rocks are, for the most part, dark green, but sometimes dark reddish purple, consist mainly of coarse-grained tuff and fine to coarse-grained volcanic breccia, and contain fine grained tuff in a small amount. They include sometimes small lenses of limestome and thin beds of red chert. Lava flows are 
dark green, compact, containing abundantly amygdaloidal cavities. Tuffs, volcanic breccias and lava flows are intermingled or stratified with one another. These pyroclastic rocks and lava flows are passed comparatively rapidly into the slate with interfingering state. However, in the northern wing coarse-grained and finegrained volcanic breccias of 20 to $10 \mathrm{~m}$. in thickness are traceable for a long distance, together with a subjacent chert, in the lowest part of the upper subformation.

Chert is developed in two layers in the upper subformation, one is in the lowest part and the other is in the upper part. The former has a thickness of 10 to $25 \mathrm{~m}$., and intercalates frequently a limestone layer or lens ranging from 1 to $2.5 \mathrm{~m}$. in thickness in its middle part. This chert is thin bedded $(2$ to $5 \mathrm{~cm}$. in thickness), and is generally white grey to dark grey in color. The upper one is 1 to $5 \mathrm{~m}$. in thickness, usually dark red to brownish red in color, and frequently accompanied lenticular limestones. The limestone in turn, generally contains angular fragments of various sizes of pyroclastic rocks. It is sometimes tuffaceous and crystalline everywhere.

The upper limit of the upper subformation is unknown owing to erosion. Fossils have not yet been discovered from the upper subformation.

\section{Fossil Faunule}

As stated above, fossils are only found in the limestones in the middle part of the lower subformation. The limestone exposed at the river-bank of the Hikawa at Tsutsui is an example, from which H. YABE and T. SugIYAma (1939) reported Diphyphyllum cf. platiforme Y $\ddot{\mathrm{U}}, \mathrm{D}$. cf. gracile McCoy, Siphonodendron sp. (cf. S. hsinanense $\mathrm{Y} \ddot{\mathrm{U}}$ ) and Endothyra sp.

I collected fossils from the two limestone lenses at Tsutsui and from other three lenses of limestone on the tributaries of northern side of Hikawa valley from Tsutsui to Kawaiba. In my collection the following corals and foraminifera have been identified.

Dibunophyllum cf. kankouense YÜ

Oxueichouphyllum latifossulatum KANMERA n. sp.

k 
Diphyphyllum platiforme YÜ var. kakisakoense KANMERA n. var.

Siphonodendron sp.

Hexaphyllia sp. A

Millerella japonica KANMERA n. sp.

Millerella gigantea KANMERA $\mathrm{n}$. sp.

Millerella sp. A

Millerella (?) sp. B

Endothyra sp.

Saccamminopsis carteri (Brady)

Besides these fossils, few undetermined fragmental corallites of Tetracoral, some small foraminifera and few specimens of trilobite and brachiopod were obtained from the limestone at Tsutsui.

Among these fossils, corals occur sporadically throughout the whole thickness of the limestone, but they are little in amount. Their preservation is comparatively good, but the thecarium is perfectly filled with fine grains of quartz by secondary replacement. Millerella occurs fairly commonly in the upper part of the limestones, abundantly in a limited part, and rarely in the lower part. It is more or less compressed by subsequent deformation.

\section{Correlation}

A glance at the fossil listed above leads us to remark that it shows a close similarity to the fauna of the Upper Visean age. This is revealed in the assemblage of genera. I will attempt, here, to compare in detail the constituting species with those of other provinces.

Dibunophyllum cf. kankouense Yن̈ belongs to the group of D. bristolense Garwood and Goodyear, and is closely similar to D. bristolense var. kankouense Yü. The occurrence of the typical form of $D$. bristolense is restricted to D2 to D 3 subzones of Dibunophyllum zone (D zone) of the Upper Viséan in England (R. C. Moore, 1947 after D. Hill (1938)). While, D. bristolense var. kankouense was described by YU் (1933) from the Yuanophyllum zone in southern China, which is regarded as the equivalent of the Upper Viséan. Futhermore, D. bristolense and its varieties were described by M. Minato (1943) from the Onimaru series in the 
Kitakami massif of northeastern Japan, which is correlated to the Upper Viséan.

$K$ Queichouphyllum is one of the diagnostic genera in the Yuanophyllum zone in China where a number of species have been described by $\mathrm{YU}$ and others. The genus was found also from the Onimaru series by M. Minato. d. 'iatifossulatum n. sp. is akin to yabei Minato.

A new variety of Diphyphyllum platiforme Yü shows a close resemblance in the essential characters to $D$. platiforme, and the latter occurs in association with Yuanophyllum in China.

As Hexaphyllia sp. A has been identified only in transeverse sections owing to the insufficiency of materials, I have been unable to determine the species. The generic determination is convincing because the fossil is in good state of preservation. The genus occurs in the Lower Carboniferous of Scotland and Central Russia. Three species of Hexaphyllia have been known in Asia. Namely, H. YABE and T. Sugryama (1939 and 1940) described them from the Onimaru limestone.

The most primitive fusulinid genus Millerella has a geological range from the late Mississippian to the Upper Pennsylvanian in north America, and the earliest representative of Millerella is found in the Chester series of Upper Mississippian by ZELLER (1949). In Asia, species of Millerella have been reported from the limestone of the Onimaru series by H. YABE (1949), and from the Gigantella latissimus horizon of the upper Lower Carboniferous in Manchuria by M. Minato (1950). M. japonica n. sp. agrees approximately in the size of test with Millerella sp. discovered by $H$. YABE from the Onimaru limestone, but other two species from Kakisako are dissimilar to any other known species.

Although some of paleontologist do not regard Saccamminopsis as fossil remains of organism, it is well known that Saccamminopsis carteri (Brady) occurs commonly from the limestone of the Upper Viséan age in Europe and Asia.

Judging from the fossils noted above, the limestone containing them is no doubt assigned to the Upper Viséan stage, being correlated to the Onimaru stage of the Kitakami massif.

Besides the occurrence of fossils stated above fossil remains have not yet unfortunately been found in the lowest and the uppermost parts of the lower subformation and throughout the 
upper subformation of the Kakisako formation. In consequence the geological ages of these horizons are not definitely settled and can only be vaguely inferred from their conformable relation to the limestone of the lower subformation.

Acknowledgement: Prior to entering into the description of fossils, I wish to express my hearty thanks to Prof. T. MATSUMOTO of Kyushu University, for his continuous guidance and for his kindness in reading the manuscript on the stratigraphy in this paper, and to Assist. Prof. R. ToRIYAMA of same University, for his kindness in reading the manuscript on the description of fossils and for his valuavle advice. I am greatly indebted also to Dr. M. Minato of the Department of Geology, Hokkaido University, for his special guidance on the study of coral and his criticism. I also express my gratitude for the financial help provided by the Educational Department.

\section{Description of Species}

\section{Order Tetracoralla Haeckel}

Family Cyathophyllidae EDWARDS and HAIME, 1850

Genus Paleosmilia Edwards and HaIme, 1848

Subgenus Kueichouphyllum YÜ, 1931

Kueichouphyllum latifossulatum KANMERA n. sp.

Pl. VIII, Figs. 1-8, 1a, 4a.

Corallum simple, very large, attaining more than $150 \mathrm{~mm}$. in length, cylindrical in mature stage, but slightly curved ceratoid in young stage. External characters unobservable, being the specimens entirely embedded in the matrix. Epitheca very thin. Septa very numerous, as m'xch as 210 in number, including major and minor ones in the corallite about $50 \mathrm{~mm}$. in diameter. Of them about $1 / 4$ to $1 / 5$ number of the major septa reaching central area and joining with one another, while the rest of the major septa extending inwardly only about $1 / 2$ the radius of the corallite. Minor septa alternating with major ones, the length of the former attaining or only slightly over the width of dissepimentarium. All septa incluting mins and $\mathrm{m} \mathfrak{a}$ jor ones are almost straight and thin in extrathecal area, but thickened in intrathecal area, es- 
pecially so in the cardinal quadrants where the major septa are so dilated that they are almost completely fused with each other. Major septa in the counter quadrants also dilated, especially near the alar septum, but far thinner than those in the cardinal area. Dissepimentarium broad, nearly $1 / 3$ the width of the diameter of the corallite at the broadest case, where more than 15 rows of dissepiments are existed. All these dissepiments concentrically arranged.

Cardinal fossula prominent, rather broad, encircling by septa which show incomplete pinnate arrangement. Cardinal septum very short, situating in the central portion of the fossula. A number of cut-edges of the tabulae are crowded in the middle portion of the fossula.

In longitudinal section, dissepimental vesicles occupying broad peripheral zone, facing their convex side upwardly and simultaneously inwardly. At the same time, vesicles near the outer wall are smaller and obliquely arranged, while vesicles near the theca, rather larger and steeply arranged.

Tabulae numerous, incomplete, nearly horizontal or only slightly convex upwards in the central area, but more arched near the theca.

Remarks: The present species is doubtlessly most clearly ally to Kueichouphyllum yabei Minato (1943), described and illustrated from the Kitakami massif, but differs from the latter in having more broad septal break. Moreover the septa in the cardinal quadrants of the specimens now in my disposal are much thickened by stereoplasmic deposits even at the early stages of the ontogeny, and far dilated than those of $K$. yabei.

Occurrence: From the limestone at Tsutsui, Kakisako-mura; Onimaru stage.

Reg. No. GKD. 50001 (holotype), 50002

Family Clisiophyllidae Nicholson and Thomson, 1883

Genus Dibunophyllum Thomson and Nicholson, 1876

Dibunophyllum cf. kankouense $\mathrm{YU}$

PI. IX, Figs. 1-10, 1a, 2a, 4a.

1933, Dibunophyllum bristolense GARWOOD and GOODYEAR var. kankouense Y $\mathrm{U}:$ Palaeontologia Sinica, Ser. B, Vol. XII, Fasc. 3, p. 124-125, Pl. XXIII, figs. 8a-c, Pl. XXIV, Figs. 5a-c. 
Corallum simple, corallite attaining more than $130 \mathrm{~mm}$. in length, cylindrical in form in mature stage, conico-cylindrical in early one. Calyx unobservable. Outer walls mostly erroded away but faint longitudinal striations and concertric growth lines observable in some specimens.

Septal number and calicular diameter counted and measured in the serial sections, which were obtained from one corallite, are tabulated below.

\begin{tabular}{|c|c|c|c|c|c|c|c|c|}
\hline $\begin{array}{l}\text { section no. } \\
\text { calicular }\end{array}$ & $\begin{array}{cc}1 & 2 \\
20- & 22-\end{array}$ & $\begin{array}{c}3 \\
24-\end{array}$ & $\begin{array}{c}4 \\
25-\end{array}$ & $\begin{array}{r}5 \\
17-\end{array}$ & $\begin{array}{c}6 \\
15-\end{array}$ & $\begin{array}{r}7 \\
15\end{array}$ & $\begin{array}{c}8 \\
12 ?\end{array}$ & $\begin{array}{l}9 \\
?\end{array}$ \\
\hline $\begin{array}{r}\text { septal number } \\
\text { (major septa) }\end{array}$ & $\begin{array}{l}57-58 \\
58\end{array}$ & 58 & 57 & 46 & $42-$ & -37 & 32 & \\
\hline
\end{tabular}

Major septa counted as much as 57 to 58 in the corallite of full grown stage. They attain about $3 / 4$ to $2 / 3$ of radius in length, and some of them continue to septal lamellae of the central area. They are very thick at the theca, especially in the cardinal quadrants throughout all stages, and are becoming graduaIly to be thin towards both ends from the theca.

Minor septa are poorly developed, very short, and not always alternating with the major septa, attaining a length as long as $1 / 3$ to $1 / 2$ of dissepimentarium, if present; while they are wholly lacking in the early stage.

As central area occupied by the axial structure does not increase its width in harmony with the growth of the corallite, it is rather narrow in full grown stage, but well defined from the medial area. Median plate which is long and occasionally much strengthened by organic deposits bisects the columella of spider-web structure, and unites directly at the two ends with the cardinal and counter septa in most stages. Axial tabllae numerous, 9 to 13 in number on each side of the median plate in mature stage, but in latest stage they decrease in 5 to 8 , and are slightly thickened by organic deposits. They are facing their concave sides outwardly in the transverse section, especially in mature stage.

Septal lamellae are also numerous, 4 to 6 of larger ones on either side of the median plate, regularly spaced and somewhat flexuous. A few shorter lamellae, not confluent with the septa, 
exist between the major ones.

Fossula definitely present in the mature stage, but rather doubtful in the early stage.

Dissepimentarium increasing its broadness as the corallite grows, usually about $2 / 3$ or a little more the length of the major septa. It consists of very numerous dissepiments, which are arranged in angulo-concentric pattern and more densely crowed near the theca, while they show outwardly the herring-bone arrangement.

In the longitudinal section, outer zone is occupied by oblique rows of unequal sized vesicles, which are facing their convexsides inwardly at the theca, but upwards as well as inwards near the outer wall. Axial tabellae highly inclined from the median plate are rather straight or little concave, quite dense and imbricate with one another, while the tabulae are rather conical, more loosely arranged and more or less inclined, facing their convex sides upwards as well as outwards.

Remarks: D. Hill (1938) once regarded D. bristolense to be wholy synonymous with $D$. bipartitum, but I have some doubt whether his identification is correct or not. Setting this point for a little while, I also doubt that Yư's specimens described and figured from the Lower Carboniferous of China should be identified with Garwood and Goodyear's specimens under the same specific name. The Chinese specimens show always to have much thickened median plate and more conical tabulae in the longitudinal sections, the features must be not neglected as important character to compare these corals.

Under such circumstances, I am in the opinion that the YU's specimens should be distinguished specifically from the European coral treated under the name of $D$. bristolense, and I should like to call the YÜ's specimens as $D$. kankouense Yü.

So far as my opinion is concerned, it is almost beyond doubt, that the Japanese specimens now at my disposal may be most nearly ally to this Chinese species, however, the axial tabellae of Japanese specimens show to be more densely crowded and more steeply inclined than the Chinese one, and the tabulae of the Japanese specimens are more conical, and therefore I hold the present specific identification as tentative until more sufficient materials are collected in future. 
Occurrence: From the limestone at Tsutsui and from the limestone in the tributary between Tsutsui and Hutae, Kakisako-mura.

Reg. No. GKD. 50014-50018

Family Lithostrotiontidae Grabau, 1927

Genus Diphyphyllum Lonsdale 1845

Diphyphyllum platiforme Yü var. kakisako-

ense KANMERA $n$. var.

Pl. IX, Figs. 1-15.

1933, Diphyphyllum platiforme Yü: Palaeontologia Sinica, Ser. B, Vol. XII Fasc. 3, p. 84, Pl. XV, Figs. 3a-b, Pl. XVI, Figs. 4a-b.

1939, D. cf. platiforme YABE and SugIYAMA: Proc. Imp. Acad. Tokyo, Vol. XV, p. 300 , Figs. $2-5$.

Corallum composite, fasciculate, forming a colony over $20 \mathrm{~cm}$. broad, and consisting of numerous, flexuous, cylindrical corallites, which are somewhat irregularly arranged, and are separated from another at a variable distance. Calyx rather deep. Epitheca quite thin, and its external surface is ornamented by annulated wrinkles and striae. Diameter of the corallites attains almost 4.5 to $5.0 \mathrm{~mm}$., being very rare beyond $5.0 \mathrm{~mm}$.

Major septa 18 in number, rarely 19, in mature stage, about $1 / 3$ as long as the diameter, alternating with the equal number of minor ones. The minor septa in the earliar stage are always shorter than $1 / 2$ the length of the major ones and are confined to the extrathecal area, but in the mature stage most of them extend to the inrathecal area for some distance, being about $2 / 3$ as long as the majar ones. All the septa are moderately thick, diminishing in thickness towards the distal ends. The inner ends of the major septa are either interrupted by an incomplate inner wall, or partly penetrate the downward deflected portion of tabulae for a short distance inwards.

Dissepimental zone consists of only one row or frequently two rows of vescicles, which are nearly equal in size and shape, their convexity facing inwards and upwards.

Tabulae are nearly flat in the central portion and bent abruptly downward at the sides. Although some of them may overlap the preceding ones, most of them are generally not in 
contact with the preceding ones at the margin, extending obliquely to the inner sides of the dissepimental zone. They are rather regularly spaced, about 6 in a vertical distance of $5 \mathrm{~mm}$., occupying a central space little than $1 / 2$ the diameter of the corallite.

The narrow space between the dissepimental and tabulate zones is commonly wider or sometimes narrower than the width of the dissepimental zone and is traversed by the down bent margins of the tabulae and small outer tabulae, which are concave upwardly and mainly slope downwards and upwards.

Remarks: In the diameter of the corallites and the number of septa, this species is quite similar to D. platiforme YÜ (1933) from the Yuanophyllum zone of China. In the latter, however, the minor septa are confined at the intrathecal area, the inner wall is complete, and the vessicular dissepiments are almost arranged in one row, while in this form the minor septa are slightly longer and protruded for a short distance to the intrathecal area in the mature stage, the dissepimental vesicles are frequently arranged in two rows, and the deflected portion of the successive tabulae does not unite mainly to form an inner wall. These facts may be sufficient to distinguish the present form from the latter species as its varietal form.

Occurrence: From the limestone at Tsutsui, Kakisako-mura; Onimaru stage.

Reg. No. GKD. 50003 (holotype), 50004-50012

\title{
Genus Hexaphyllia Stuckenberg, 1904 Hexaphyllia sp.
}

\author{
Pl. VIII, Figs. 9-11.
}

There are only three transverse sections of corallum belonging the Hexaphyllia in my hand, among which two specimens (P1. VIII, Figs. 9 and 10) have a close resemblance in form of corallite and a similar arrangement of septa on each other. Perhaps they seem to be conspecific. They are of hexagonal outline in transverse sections and are provided with six prominent longitudinal ridges in position corresponding to the outer border of septa. The other (Pl. VIII, Fig. 11) is small, of nearly oval outline in transverse section and is not provided with so prominent ridges 
as in the former two. This specimen has a thickened septa by organic deposits and has well developed tabulae. Therefore this specimen may be not conspecific to the former specimens. However, present forms are now specifically indeterminable because of the insufficiency of materials. Moreover, as I have no oppotunity of reading the publication by Dr. P.M. DUNCAN as to the species of Hexaphyllia, I wish to postpon for a while the specific identification, until more numerous materials are collected in future. But these specimens now in hand are dissimilar to the species described and figured by $H$. YABE and $T$. SugIYAMA from the Onimaru limestone in the Kitakami massif, and from a species reported by A. STUCKENBERG from the Lower Carboniferous in Central Russia.

Reg. No. GKD. 50021, 50022, 50023

\section{Order Foraminifera d'Orbigny, 1826 \\ Family Fusulinidae Möller, 1878 \\ Genus Millerella Thompson, 1942 \\ Millerella japonica KANMERA n. sp.}

Pl. XI, Figs. 1-19, Pl. XII, Figs. 1, 2.

Shell minute, discoidal in shape; with subangular to narrowly rounded periphery, convex lateral slopes and depressed or umbricated axial regions; the inner two to three volutions involute but the outer one or two volutions of mature specimens become partially evolute. Mature specimens of four to four and one-half volutions $0.17-0.27 \mathrm{~mm}$. long and $0.74-0.93 \mathrm{~mm}$. wide. Form ratio $1: 0.21-0.29$, averaging $1: 0.23$ for 10 specimens. Average form ratios of the first to the fifth volution of 9 specimens $1: 0.41,1: 0.34$, $1: 0.31,1: 0.25$ and $1: 0.23$, respectively. Proloculus minute, outside diameter 57-86 microns, averaging 69 microns for 13 specimens.

Shell expands slowly and uniformly in inner two volutions but is more rapidly inflated in outer two volutions of mature specimens. Average heights of the first to the fifth volution of 15 specimens $41,61,81,125$, and 151 microns, respectively. Septa unfluted throughout of the length of shell. Chomata unobservable.

Spirotheca thin, composed of a dense central layer and thin, 
less dense upper and lower layers. Thickness of spirotheca of the first to the fifth volution are 7-10, 8-13, 10-15, 11-18, 11-20 microns, respectively, averaging $8,11,13,14$ and 14 microns, respectively for 15 specimens.

Septa thin, slightly curved in outer volutions. Septal counts of the first to the fifth volution are $7-8,11-12,15-16$ and $17-19$, averaging $7,12,15,18$, respectively for six specimens. Septa on the first volution are nearly normal to the overlying spirotheca,

\begin{tabular}{|c|c|c|c|c|c|c|c|c|c|c|}
\hline $\begin{array}{c}\text { Speci. } \\
\text { men }\end{array}$ & $\begin{array}{c}\text { No. } \\
\text { of } \\
\text { vol. }\end{array}$ & Length & Width & Ratio & $\begin{array}{c}\text { Dia. of } \\
\text { plolo- } \\
\text { culus }\end{array}$ & \multicolumn{5}{|c|}{ Height of volutions } \\
\hline 1 & 5 & .200 & .932 & .21 & .072 & .043 & .057 & .079 & .128 & .151 \\
$2^{*}$ & $43 / 4$ & .179 & .930 & .19 & .061 & .036 & .050 & .075 & .136 & .179 \\
3 & 5 & .207 & .879 & .24 & - & .031 & .039 & .072 & .122 & .136 \\
4 & 5 & .272 & .930 & .29 & .068 & .043 & .047 & .057 & .129 & .186 \\
$5^{*}$ & $43 / 4$ & .186 & .829 & .22 & - & - & .057 & .075 & .128 & .128 \\
6 & $41 / 2$ & .186 & .686 & .27 & .057 & .043 & .057 & .079 & .129 & .143 \\
7 & $41 / 2$ & .172 & .744 & .23 & - & .036 & .043 & .073 & .122 & .129 \\
8 & $41 / 2$ & .214 & .744 & .28 & .057 & .013 & .057 & .086 & .114 & .157 \\
9 & 4 & - & .700 & - & .065 & .043 & .057 & .086 & .129 & - \\
10 & 4 & - & .801 & - & .086 & .051 & .060 & .089 & .120 & - \\
$11^{*}$ & $41 / 2$ & - & .829 & - & .072 & .041 & .057 & .081 & .122 & .129 \\
$12^{*}$ & $33 / 4$ & - & .751 & - & .079 & .039 & .057 & .083 & .124 & - \\
\hline
\end{tabular}

\begin{tabular}{|c|c|c|c|c|c|c|c|c|c|c|c|c|c|c|c|}
\hline $\begin{array}{c}\text { Speci- } \\
\text { men }\end{array}$ & \multicolumn{3}{|c|}{ Thickness of } & \multicolumn{2}{l|}{ spirotheca } & \multicolumn{2}{|c|}{ Septal number } & \multicolumn{3}{|c|}{ Form ratio } \\
\hline & 1 & 2 & 3 & 4 & $41 / 2-5$ & 1 & 2 & 3 & 4 & 1 & 2 & 3 & 4 & 5 \\
\hline 1 & .010 & .010 & .013 & .011 & - & - & - & - & - & .37 & .33 & .30 & .21 & .20 \\
2 & - & .008 & .010 & .011 & - & - & - & - & - & - & .26 & .23 & .20 & .19 \\
3 & - & .010 & - & .016 & .014 & - & - & - & - & - & .38 & .40 & .29 & .24 \\
4 & .011 & - & .012 & .015 & .015 & - & - & - & - & .41 & .38 & .36 & .31 & .25 \\
5 & - & .010 & - & .014 & - & - & - & - & - & - & .37 & .33 & .26 & .22 \\
6 & .007 & .010 & .016 & .012 & .011 & - & - & - & - & .50 & .43 & .33 & .26 & .26 \\
7 & - & .011 & .010 & .009 & - & - & - & - & - & .40 & .30 & .28 & .26 & .20 \\
8 & .009 & .010 & .012 & .013 & .015 & - & - & - & - & .40 & .34 & .31 & .28 & .27 \\
9 & .008 & .013 & .015 & .017 & - & 7 & 12 & 16 & - & - & - & - & - & - \\
10 & .010 & .012 & .014 & .018 & - & 8 & 12 & 15 & 17 & - & - & - & - & - \\
11 & .007 & .009 & .013 & - & - & 7 & 12 & 15 & 19 & - & - & - & - & - \\
12 & .009 & .013 & .014 & .014 & - & 7 & 12 & 15 & 18 & - & - & - & - & - \\
\hline
\end{tabular}

* deformed 
but beyond the first volution septa extend anteriorly and are at an angle of about 25 degrees from normal to spirotheca in outer volutions.

Remarks: Present species agrees approximately in size of shell with Millerella sp. reported by Yabe (1949) from the limestone of the Onimaru series in Kitakami-massif, northeastern Japan. Although both may probably be a same species, an identification between Yabe's species and the present one cannot precisely be determined, because the specimens illustrated by Yabe are all ill-oriented sections and his description is too briefly.

The present species is distinguished from any previously described species in having a large size of shell, highly inflated volutions, small form ratios and indistinct chomata.

Occurrence: Millerella japonica occurs in the upper part of the limestone lenses in the middle part of the lower subformation, and are obtained fairly commonly in the limestone exposure at Tsutsui and at the tributary of northern side of Hikawa between Hutae and Kawaiba; associated Dibunophyllum cf. kankouense and Kueichouphyllum latifossulatum KANMERA n. sp. and other Upper Viséan corals.

Reg. No. GKD. 10001, 10002, 10004 (holotype), 10006, 10007, 10009, 10012, 10013, 10015-10019, 10024

\title{
Millerella gigantea KANMERA n. sp.
}

\author{
Pl. XII, Figs. 4-14.
}

Shell minute, subdiscoidal in the axial profile; with slightly depressed axial regions, broadly rounded periphery and distinctly convex lateral slopes. Mature specimens of four volutions 0.33$0.35 \mathrm{~mm}$. long and $0.9-1.15 \mathrm{~mm}$. wide. Form ratios of mature specimens $1: 0.32-0.36$. Form ratios of the first to the fourth volution of the holotype $1: 0.5,1: 41,1: 40$ and $1: 0.35$, respectively. The first volution is evolute, the second volution essentially involute and the third and the fourth volution become slightly evolute. Proloculus minute, its outside diameter measures 72 to 86 microns in four specimens.

Shell expands rapidly and uniformely. Heights of the first to the fourth volution of the holotype 57,100,143 and 179 microns, respectively. Heights of the first to the fourth volution of three 
paratypes $57-64,86-107,114-129$ and 150-186 microns, respectively.

Spirotheca is composed of a thin dense central layer and thicker and less dense outer layers. Thickness of spirotheca of the first to the third volution of the holotype measure about 10 , 10 and 16 microns, respectively. Thickness of spirotheca of the second to the fourth volution of four paratypes measure about 8-11, 9-13, 13-18 and 13-21 microns, respectively.

Septa are straight and are essentially normal to the overlying spirotheca throughout all volutions. They are relatively thick and seem to contain a dark thin central layer and less dense outer layers, but the detailed structure of the septa is difficult to determine in most specimens. Septal counts of the first to the fourth volution of three specimens are 8-9, 12-13, 15-17 and $18-19$, respectively. Low and narrow chomata occur in inner one or three volutions, and the tunnel angle is about 19-22 degrees.

Remarks: This form is one of the largest species of Millerella and Paramillerela known from North America and Asia. In general shape present species resembles somewhat closely Paramillerella circuli (Thompson) $(1945,1951)$ from the Belden formation of North America. However, the present species is distinguished from Paramillerella circuli in having larger shell, more inflated volutions and smaller form ratios for corresponding volutions, and less distinct chomata.

$M$. gigantea can also be distinguished from $M$. japonica KANMERA from the the same localities of the Kakisako formation by its larger shell, larger form ratios for corresponding volutions, more highly and rapidly inflated volutions, more broadly rounded periphery, and the presence of chomata in the inner volutions.

Occurrence: Same to the former species.

Reg. No. GKD. 10010, 10014-10021, 10022 (holotype), 10026, 10028

\section{Millerella sp. A}

P1. X, Figs. 11-15

Shell minute, discoidal, with slightly umblicate axial regions, convex lateral slopes and broadly to narrowly rounded periphery. Inner two to three volutions are involute, but the last volution becomes slightly evolute. Specimen of four and one-half volutions $0.214 \mathrm{~mm}$. long and $0.586 \mathrm{~mm}$. wide, and the other one of four 
volutions $0.429 \mathrm{~mm}$. wide. Form ratio is $1: 0.37$.

Proloculus minute, outside diameter about 43 to 46 microns. Shell tightly coiled and uniformely expands. Heights of the first to the fourth volutions are $29-35,39-42,57$ and 79 microns, respectively.

Spirotheca thin and composed of a tectum and thin upper and lower layers. Average thickness of spirotheca of the first to the fourth volution of three specimens 8, 9-10, 11-13 and 9-12 microns, respectively. Septal structure similar to that of spirotheca. Septa slightly arcuate in center of shell. Septal counts of the first to the fourth volution in a good preserved specimen 6 (?), 11, 16 and 16 , respectively. Low and narrow chomata occur in inner two or three volutions, but not in outer volutions.

Remarks: Present species is similar to Millerella marblensis Thompson (1942, 1944, 1945 and 1948) than any previously described species in statistical data in inner volutions. However, the outer volutions of the present form are not so highly evolute and the septa are not so distinctly curved as in $M$. marblensis. This species differs from $M$. japonica described above in that it is smaller in size, having more tightly coiled shell and more rounded periphery.

Occurrence: Same to the former species.

Reg. No. GKD. 10003, 10012, 10033, 10034, 10036

\section{Millerella? sp. B}

Pl. XII, Figs. 15-17.

Several sections referable with question to the genus Millerella were obtained. These specimens are not conspecific with any previously described species. For completeness, some of better specimens are illustrated and the following description is based on them which are perhaps conspecific.

Shell minute, subdiscoidal in shape, narrowly and rather deeply umbricate; with broadly rounded periphery and strongly convex lateral slopes. Specimens of three to three and a half volutions $0.20-0.22 \mathrm{~mm}$. long and 0.50 to $0.61 \mathrm{~mm}$ wide. From ratios $1: 0.33-0.36$. All volutions slightly evolute. Shell umbricates throughout the growth. 
Proloculus 64 to 93 microns in its outside diameter. Heights: of the first to the third volution $46-57,72-85$, and 128-157 microns, respectively. Spirotheca composed of a dense central layer and less dense outer layers. Thickness of spirotheca of the first to the third volution 10-13,12-14 and 12-15 microns, respectively. Chomata indistinct.

Remarks : Present species does not referable to any previously described species by having broadly rounded periphery, strongly convex lateral slopes, roundly inflated outer volution and indistinct chomata. However, the specific determination of the present species is impossible owing to the insufficient materials for the detailed observation.

Occurrence: Same to the former species.

Reg. No. GKD. 10013, 10032

\section{References}

CHI, Y.S., 1931, Weiningian (Middle Carboniferous) Corals of China, (Palaeontolongia Sinica, Ser. B. Vol. XII. fasc. 5.)

- 1935, Additional fossil Corals from the Weiningian Limestones of Hunan, Yunnan and Kwangsi Provinces, in SW China (Palaeontologia Sinica, Ser., B, Vol. XI, fas:. 6.)

GARwooD, E. J. 1912, The Lower Carboniferous succession in the north-west of England: (Quat. Jour. Geol. Soc. London, Vol. 68, pp. 445-572.)

- , and GOODYEAR, E. 1922, The Lower Carboniferous succession in the Settle district and along the line of the Craven Faultes. (Q. J. G.S., Vol 80.)

GrabaU, A.W. 1922, Palaeozoic corals of China, Part 1, Tetraseptata. (Palaeontologia Sinica, Ser. B, Vol. 2, fasc. 1.)

HAYASAKA, I. 1924, On the fauna of the Anthracolithic limestone of Omi-mura in the western part of Echigo. (Sci. Rep. Tohoku Imp. Univ. Sec. ser., Vol. VIII, No. 1.)

HILL, L. 1937-1938, A monograph of the Carboniferous rugose corals of Scotland. (Palaeontological Society Vol. XCI, part 1, Vol. XCII, part II.)

Kunth, A. 1869, Beiträge zur Kentniss fossilier Korallen, (Zeitschr. Deutsch Geol. Gesellsch., Vol. XXI.)

LEWIS, H.P. 1930, The Avonian succession in the south of the Isle of Man. (Q. J. G.S., Vol. 86.)

McCoy, F. 1894, On some new genera and species of Palaeozoic Corals and Foraminifera. (Ann. Mag. Nat. Hist., Ser. 2, Vol. III, p. 126.)

Minato, M. 1942 a, Unter Karbon fauna in der Manschrei. (Bull. Geol. Res. Inst. Manchukou, No. 106, pp. 27-46.)

- $1942 \mathrm{~b}$, Ploblems on the so-called Tienshan Transgression in Eastern Asia. (Jour. Geography, Vol. 54.) 
, $1943 \mathrm{a}$, On some Upper Viséan coral fauna from the coral limestone of the Kitakami mountainland, northeastern Honshu, Japan. (The Journal of the Shigenkagaku Kenkyusho, Vol. 1, No. 2, pp. 221-240.)

-, $1943 \mathrm{~b}$, New forms of Kueichouphyllum from the Lower Carboniferous Coral limestone of the Kitakami mountainland, northeastern Honshu, Japan: with some phylogenical considerations of the genus Kueichouphyllum and its allied genera. (The Journal of the Shigenkagaku Kenkyusho, Vol. 1, No. 1, pp. 97-113.)

, 1944, Die Transgression der Ober-Visé-Stufe im Kitakami Gebirge, Japan. (Proc. Imp. Acad. Tokyo, Vol. XX, No. 3, pp. 163-168.)

- 1947, Note on a coral of Lower Carbiniferous type from the Kwanto mountainland. (Proc. Japan Acad., Vol. 23, No. 9, pp. 121-124.)

- 1950, New discovery of Lower Carboniferous Millerella (Fusulinid Foraminifera in Manchuria). (Jour. Geol. Soc. Japan, Vol. 56, No. 658, pp. 379-382.)

MOORE, R. C. 1948, Paleontological features of Mississippian rocks in North America and Europe. (Jour. Geol., Vol. 56, No. 4.)

SANFORD, W. G. 1939, A review of the Families of Tetracorals, part I and II. (Amer. Jour. Sci. Vol. 237.)

SMITH, S. 1915, The genus Lonsdaleia and Dibunophyllum rugosum (McCoy). (Q. J. G.S., Vol. 71, pp. 218-268.)

Stuckenberg, A. 1904, Anthozoen und Bryozoen des Unteren Kohlenkalkes von Zentral Russland. (Mém. Com. Géol. Russie, n. s. No. 14, p. 72.)

Thompson, M.L. 1944, Pennsylvanian Morrowan rocks and Fusulinids of Kansas. (States Geological Survey of Kansas, Bull. 52, Part 7.)

- 1945, Pennsylvanian rocks and Fusulinids of East Utah and Northwest Colorado correlated with Kansas section. (States Geological survey of Kansas, Bull. 60, Part 2.)

- 1951, New genera of fusulinid Foraminifera Contr. (Cushman Foundation Foraminiferal Research, Vol. 11, Pt. 4, p. 115.)

- 1948, Studies of American Fusulinids. (University of Kansas Paleontological contributions. Protozoa, Art. 1.)

Thomson, J. and Nicholson, H. A. 1876, Contributions to the Study of the Chief generic types of the Palaeozoic Corals. (Ann. Mag. Nat. Hist. Vol. 17, 4th ser., No. 98 , No. 102.)

Vaughan, A. 1904, The Palaeontological sequence in the Carboniferous limestone of the Bristol area. (Q. J. G. S. Vol. LXI, pp. 181-307.)

- 1915, Correlation of Dinantian and Avonian. (Q.J.G.S. Vol. 71.)

WEDEKIND, R. 1937, Einführung in die Grundlagen der Historischen Geologie. II Band, Mikrobiostratigraphie der Korallen-und Foraminiferenzeit: pp. 20-64.

YABE, H. 1949, The Zone of Millerella. (Proc. Japan Academy. Vol. 25, No. 5, pp. 165-167.)

- and HAYASAKA, I. 1920, Atlas of fossils, Geographical research in China: (Tokyo Geographical Society.) , and - 1915-16, Palaeozoic corals from Japan, Korea and Chnia. (Jour. Geol. Soc. Japan, Vol. XXII-XXIII.) 
_- and SugIYAMA, T. 1939 a, Discovery of Lower Carboniferous corals from the Yatsushiro district in Kyushu. (Proc. Imp. Acad. Tokyo, Vol. XV, No. 9, pp. 300-304.) , and - , $1939 \mathrm{~b}$, Discovery of Hexaphyllia in the Lower Carboniferous of Japan. (Jour, Geol. Soc. Japan, Vol. XLVI, No. 552.)

- and 1940, Note on Heterophyllia and Hexaphyllia. (Jour. Geol. Soc. Japan, Vol. 47, No. 557.) 〔(Transactions of the Palaeontological Society of Japan, No. 99).]

YU், C. C. 1911, The correlation of the Fenginian system, the Chiness Lower Carboniferous, as based on the coral zones. (Bull. Geol. Soc. China, Vol. 10.) , 1933, Lower Carboniferous corals of China. (Palaeontologia Sinica, Ser. b, Vol. XII, fasc. 3.)

1924, Description of corals collected from the Maping and Huanglung limestones in South China. (Academia Sinica, Mem. Nat. Res. Inst. Geol., No. XlV, pp. 52-72.)

, 1937, The Fenginian Corals of South China. (Acad. Sinica, Mem. Nat. Res. Inst. Geol., No. XVI.)

ZELlER, E. J. 1950, Stratigraphic significance of Mississippian Endothyroid Foraminifera., (Univ. Kansas, Paleontological contributions Protozoa, Art. 4.) 
North Wing

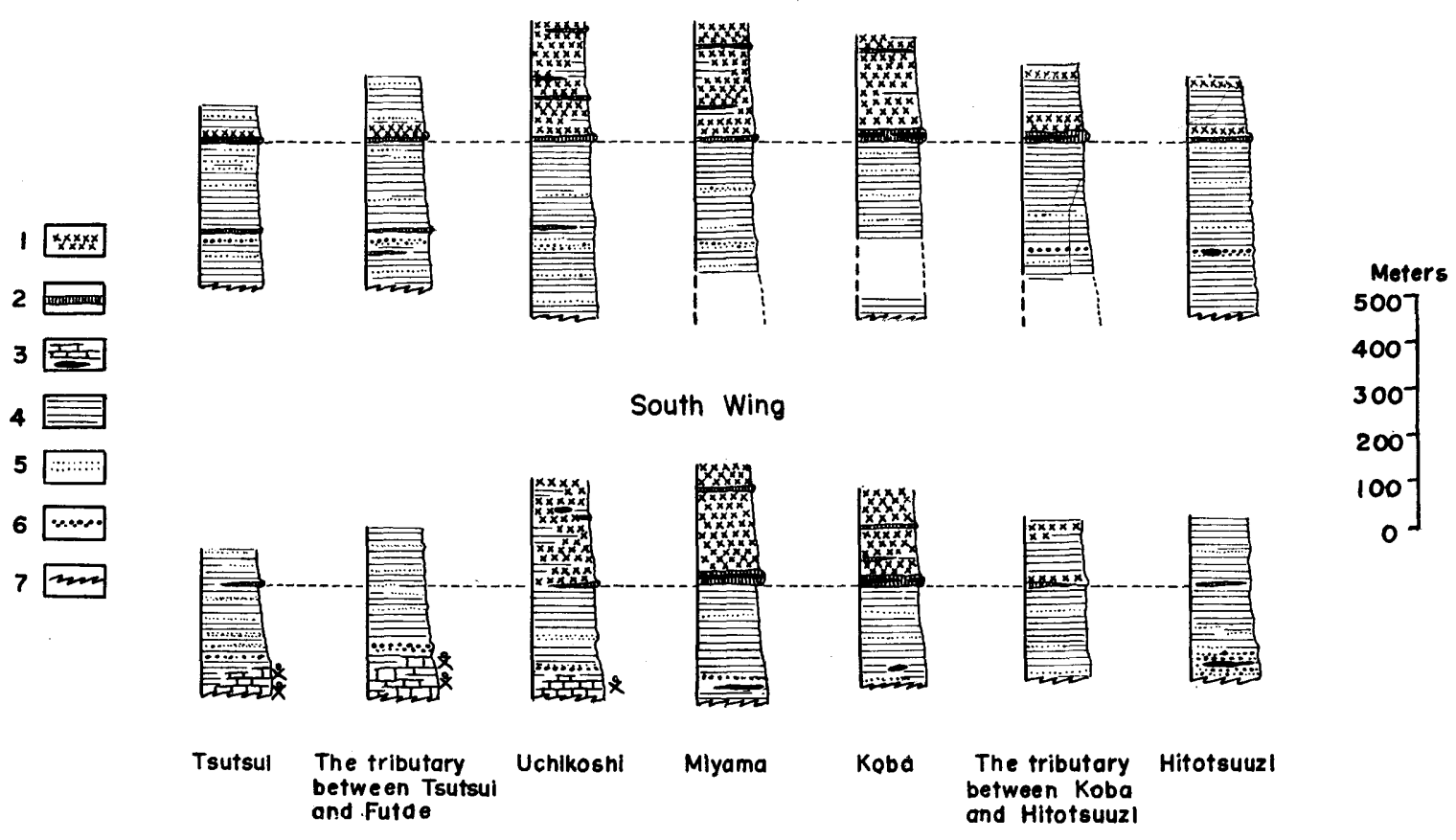

Fig. 2. Columnar sections of the Kakisako formation in Kakisako-mura district.

1. Pyroclastic rock, 2. Chert, 3. Limestome, 4. Slate, 5. Sandstoye, 6. Conglomerate, 7. Faults and thrusts. 


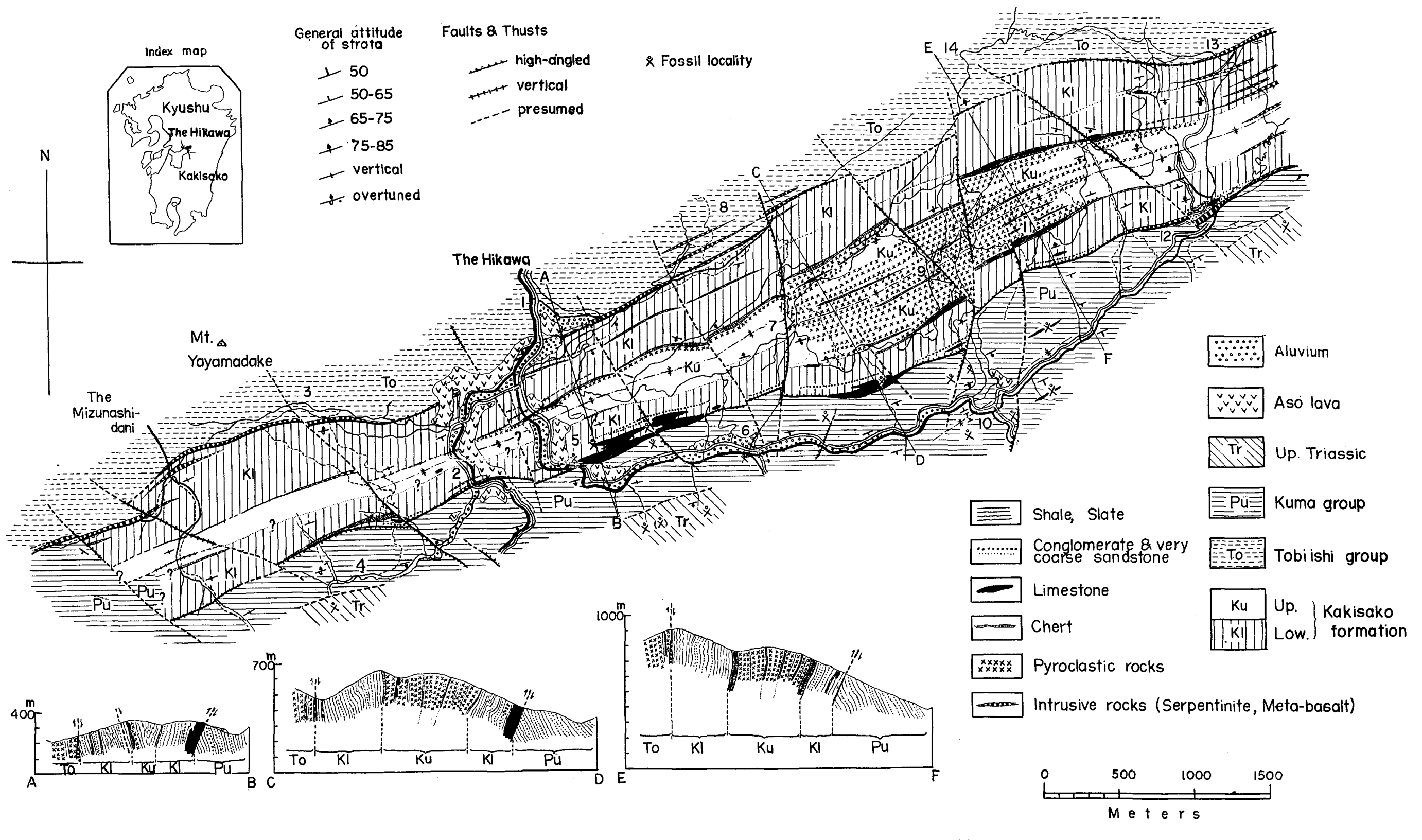

Fig. 1. Geological map and geological profiles of the Kakisako-Kuriki districts, Yatsushiro-gun, Kumamoto Pref., Kyushu.

1. Tobishi, 2. Otokawa, 3. Hiate, 4. Miyamadani, 5. Tsutsui, 6. Hutae, 7. Uchikoshi, 8. Itokawa, 9. Miyama, 10. Kawaiba, 11. Koba, 12. Hitotsuuzi, 13. Yokote, 14. Shakain 
K. KANMERA

The Lower Carboniferous Kakisako Formation of Southern Kyushu, with a Description of some Corals and Fusulinids

\section{Explanation of Plates}




\section{Explanation of Plate VIII}

\section{Figure}

1-8, 1a, 4a Kueichouphyllum latifossulatum KANMERA n. sp. Page 164

$1-8$, Successive sections of the holotype, slightly obliquely cut; retouched the highly magnified photographs; 1,2, Transverse sections of the full grown stage; 3 , Longitudinal section of the mature stage; 4,5, Transverse sections of the mature stage; 6,7,8, Transverse sections of the young stage; all $\times 1$; 1a, 4a, Same sections of Figure 1 and $4 ; \times 1.1$.

Reg. No. GKD. 50001

9-11 Hexaphyllia sp.

$9,10,11$, Transverse sections of different corallites $9,10, \times 20 ; 11, \times 30$. Reg. No. GKD. 50021, 50022, 50023 

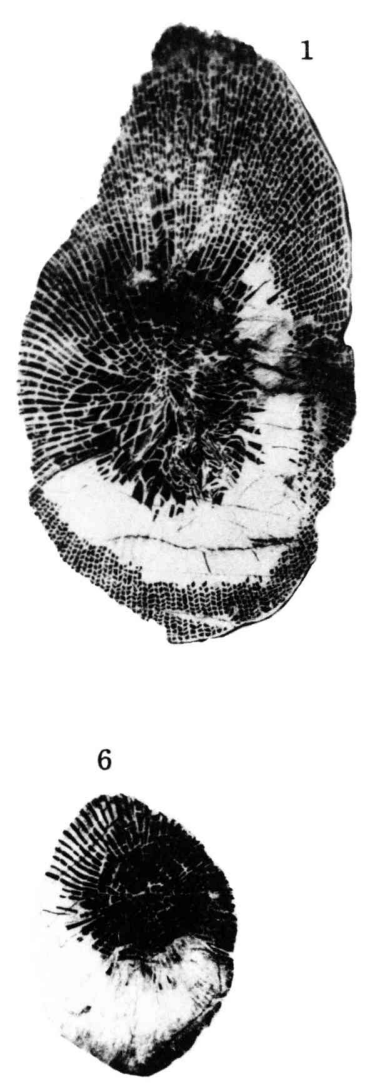
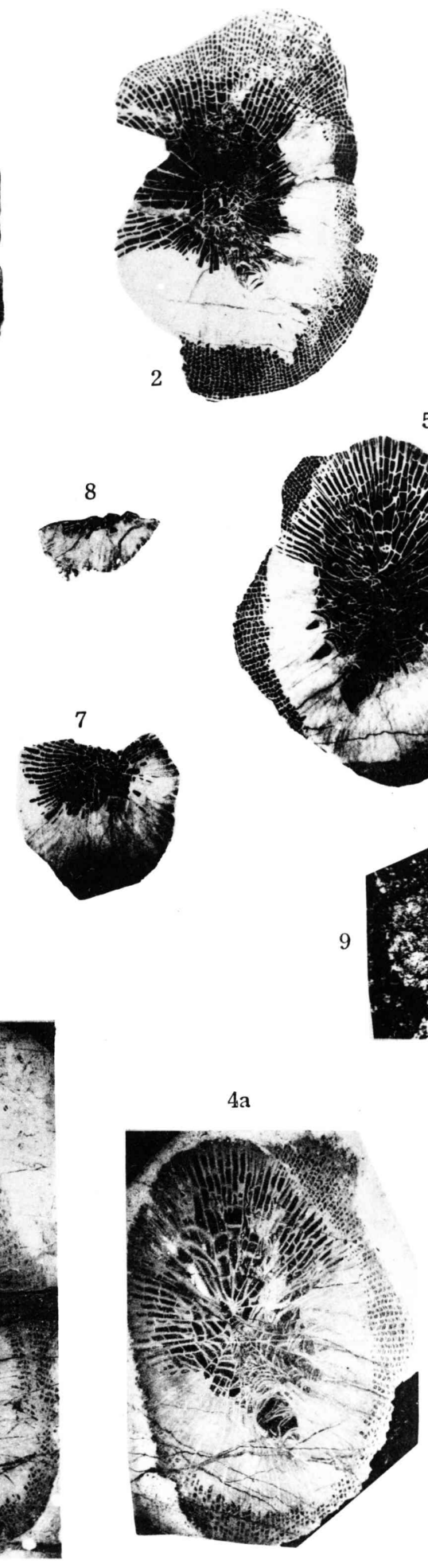

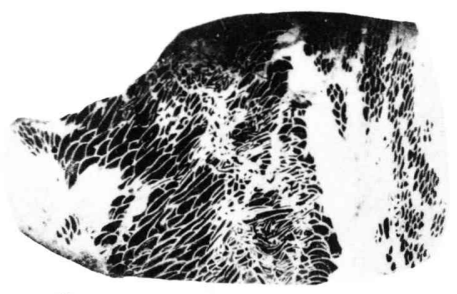

3

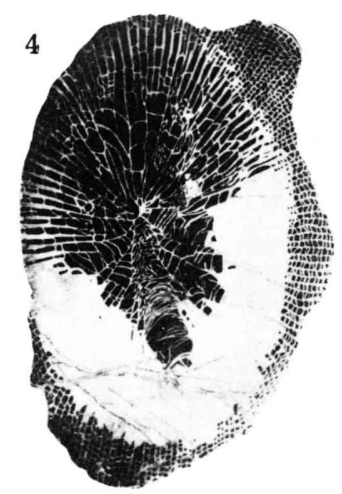

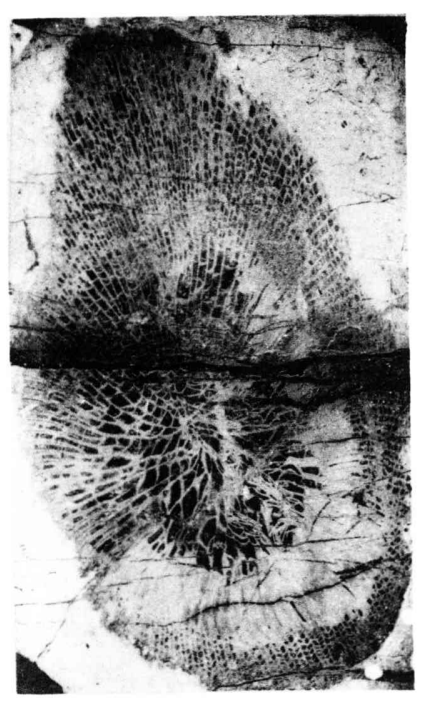
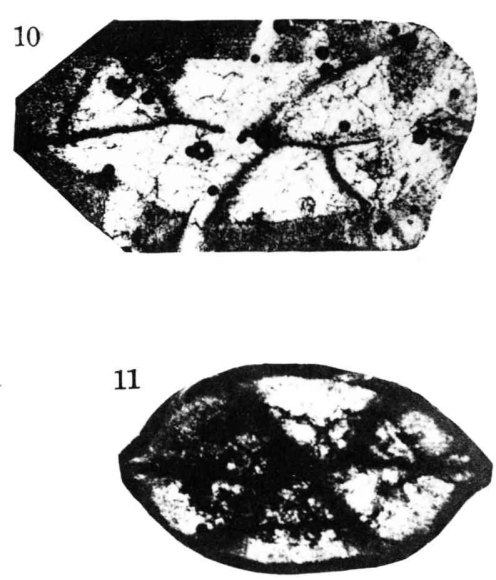


\section{Explanation of Plate IX}

\section{Figure}

1-15 Diphyphyllum platiforme Yü var. kakisakoense KANMERA n. var....Page 168 1-11, Retouched the highly magnified photographs; 1-6, Longitudinal sections, $\times 3.4 ; 7-11$, Transverse sections, $\times 3.4 ; 12-14$, Longitudinal sections and transverse sections, $\times 1.5 ; 15$, Weathered surface of the corallum, $\times 0.8$. Reg. No. GKD. 50003, 50004, 50005 

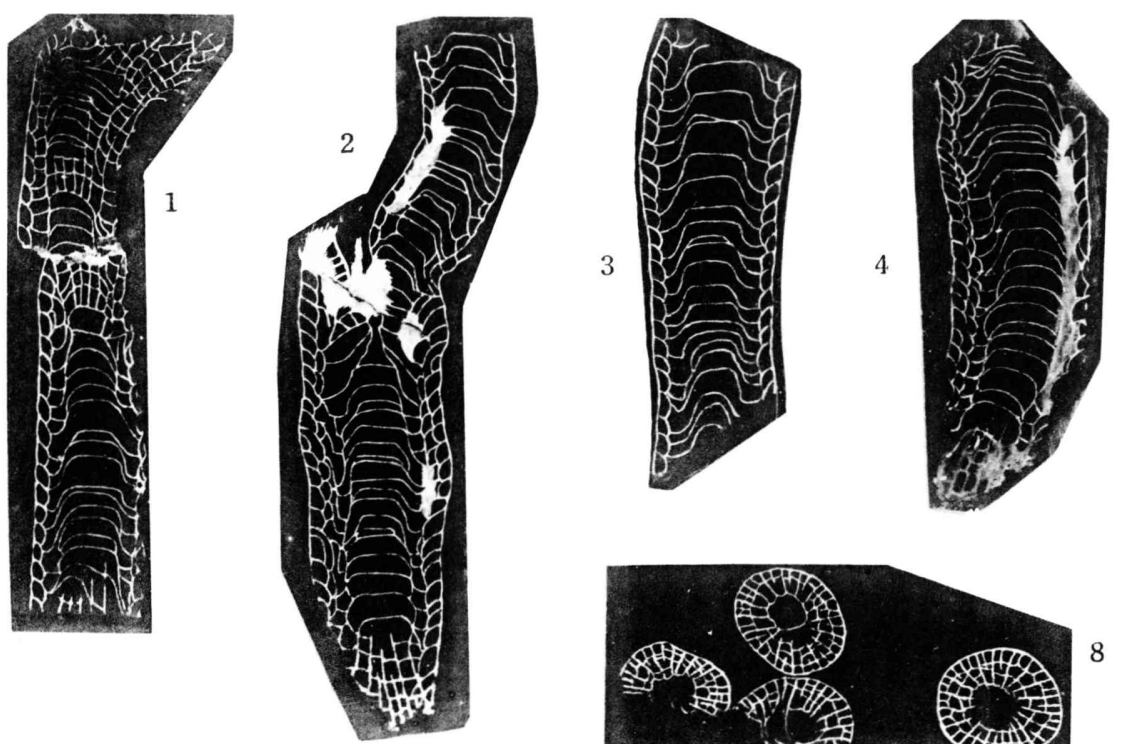

5
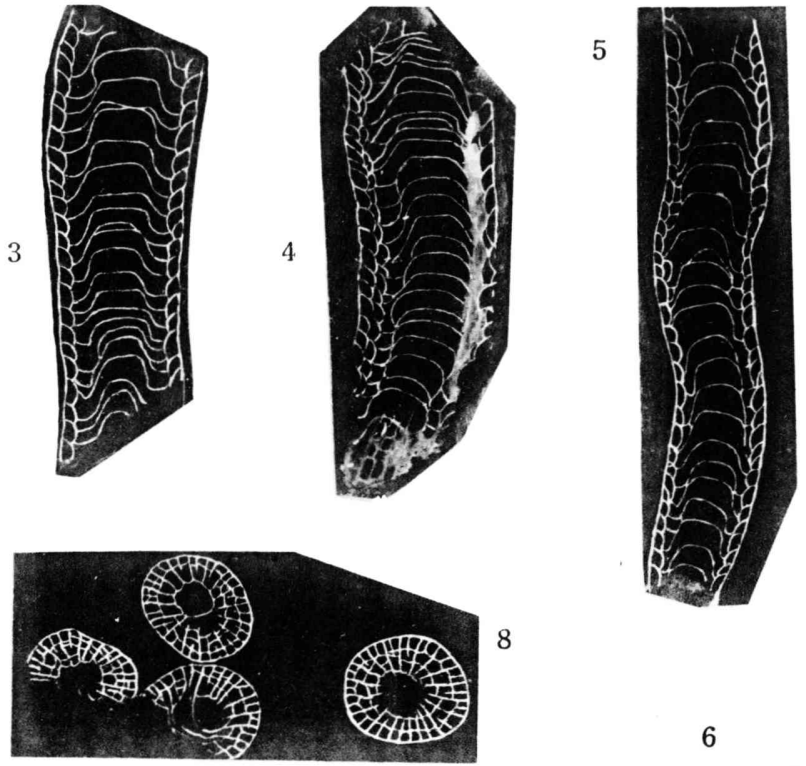
8 6
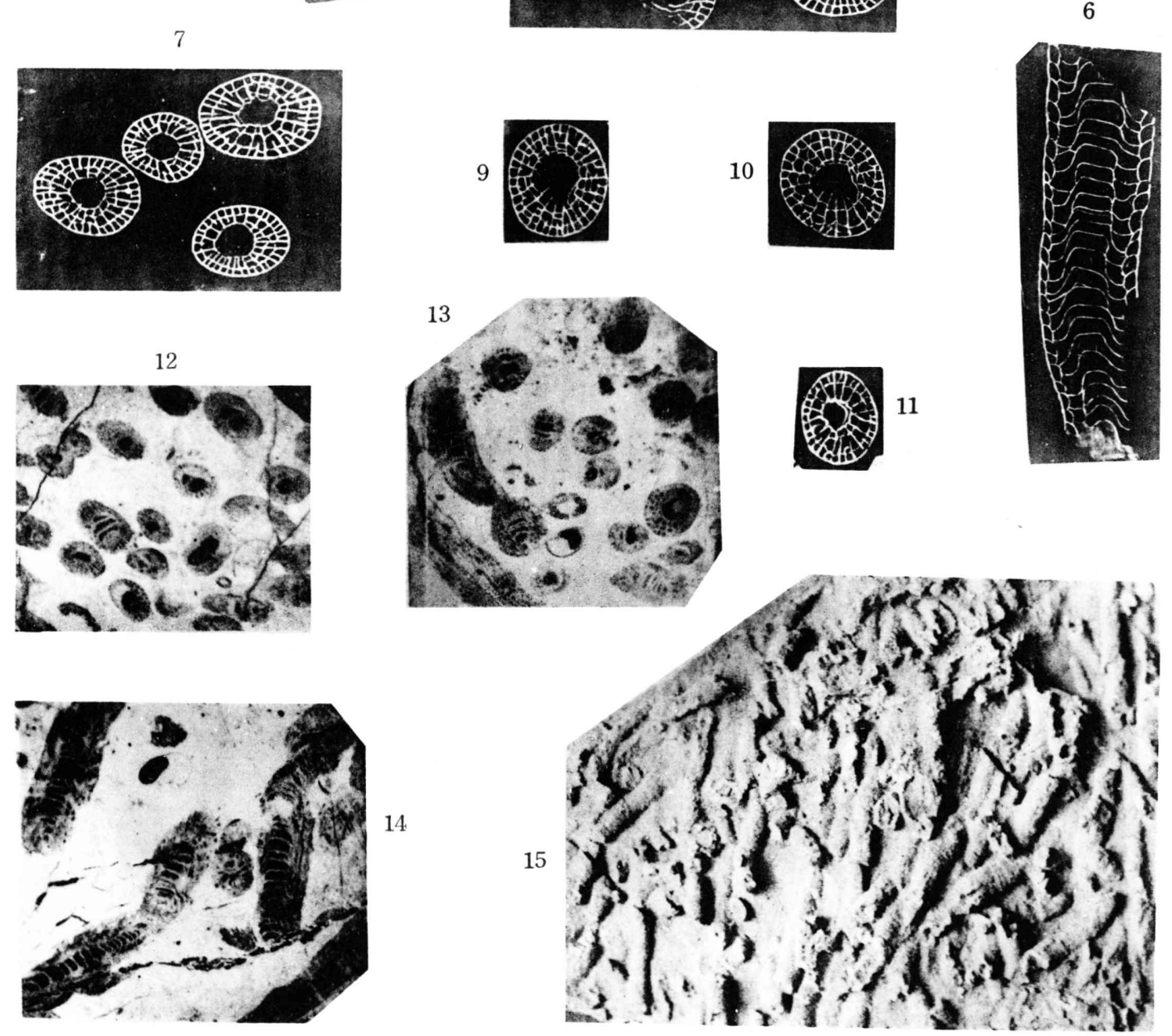


\section{Explanation of Plate $\mathrm{X}$}

Figure

1-10, 1a, 2a, 4a Dibunophyllum cf. kankouense Yü Page 165

$1-10$, Retouched the highly magnified photographs; Successive sections; all $\times 1.5 ; 1$, Transverse section of the full grown stage; 2 . Longitudinal section of the full grown stage; $3-5$, Transverse sections of the mature stage; 6 , Longitudinal section of the early mature stage; 7-10, Transverse sections of the early stage; $1 \mathrm{a}, 2 \mathrm{a}$ and $4 \mathrm{a}$, Same sections of 1,2 and 4, $\times$ 1.1. Reg. No. GKD. 50014

11-15 Millerella sp. A Page 173

11, 14 and 15, Transverse sections; 13,14 , Axial sections; all $\times 50$

Reg. No. GKD. 10003, 10012, 10033, 10034, 10036 

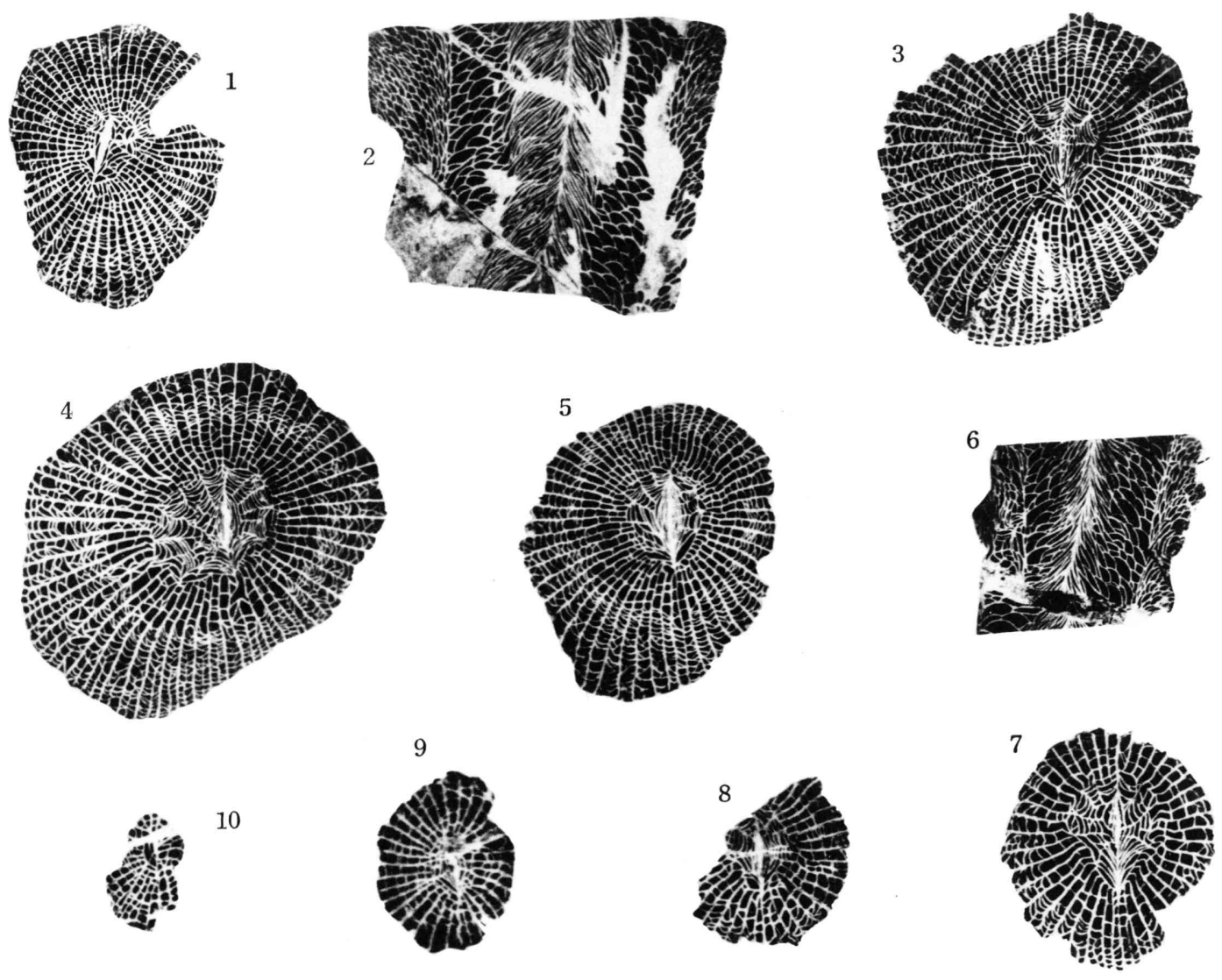

$4 a$

$1 \mathrm{a}$
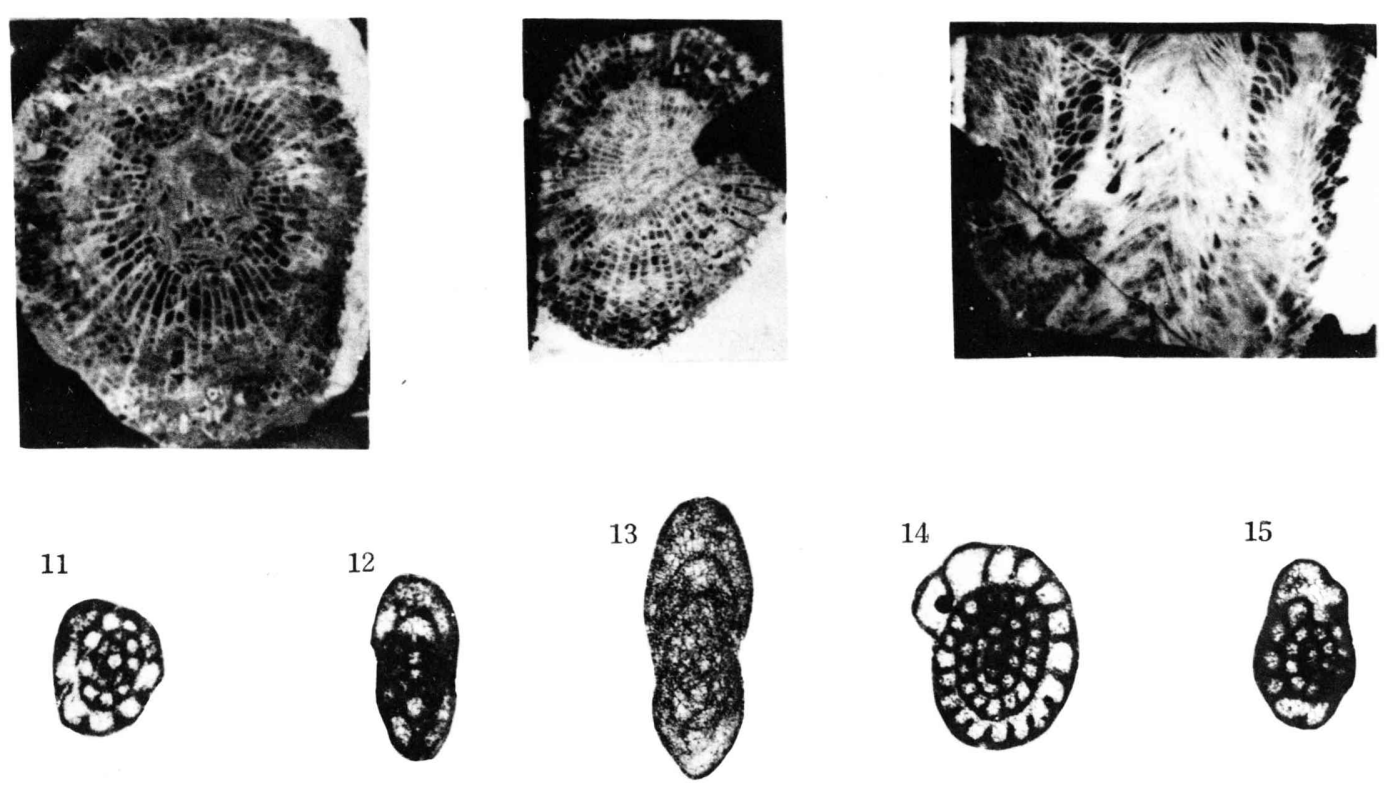


\section{Explanation of Plate XI}

\section{Figure}

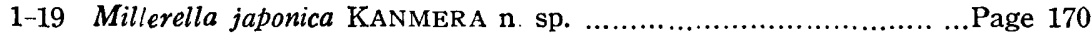

1, Axial section of the holotype; 2, 4, 5, 8-11, Axial sections of the paratype; 15-19, Sagittal sections. 3, 6, Parallel sections; all $\times 50$; Reg. No. GKD. 10001, 10002, 10004 (holotype), 10006, 10009, 10012, 10013, $10015-10019,10024$ 

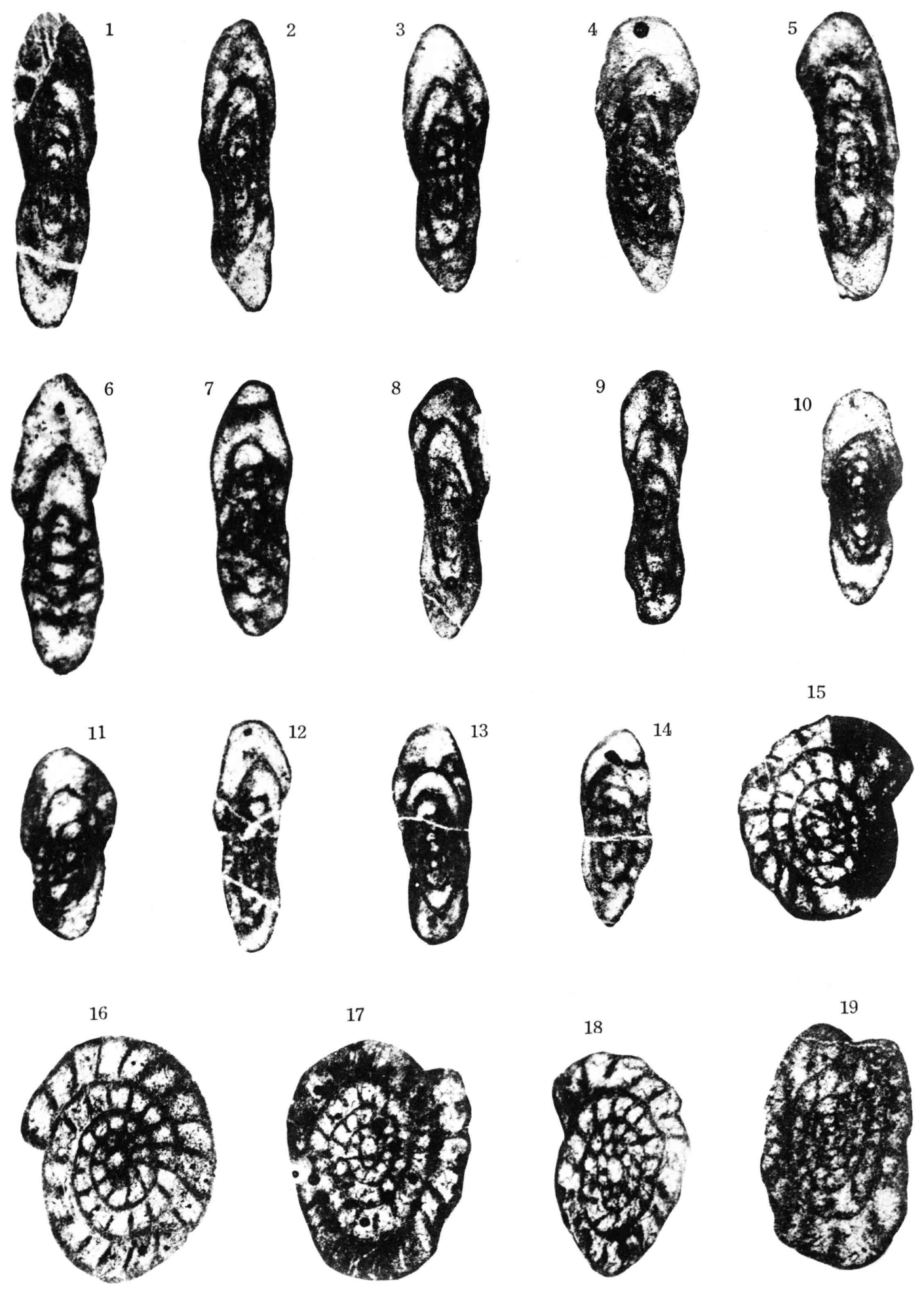


\section{Explanation of Plate XII}

Figure

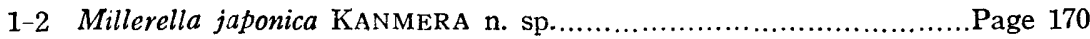

1, Axial section ; 2, Sagittal section; all $\times 50$ Reg. No. GKD. 10007, 10025

3 Millerella japonica KANMERA (?)

Sagittal section; $\times 50$. Reg. No. GKD. 10025

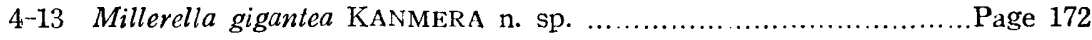

4. Axial section of the holotype (Reg No. 10022): 5, Parallel section; 6,

Axial section; 7, Oblique axial section ; 8-10, Oblique sagittal sections ; 11

Sagittal section; all $\times 50$. Reg. No. GKD. 10010, 10014-10022, 10026, 1002

14 Millerella gigantea KANMERA (?)

Parallel section; $\times 50$. Reg. No. GKD. 10032

15-17 Millerella (?) sp. B

Page 174

15, 16, Axial sactions; 17 , Oblique axial section; $\times 50$. Reg. No. GKD.

10013,10032 

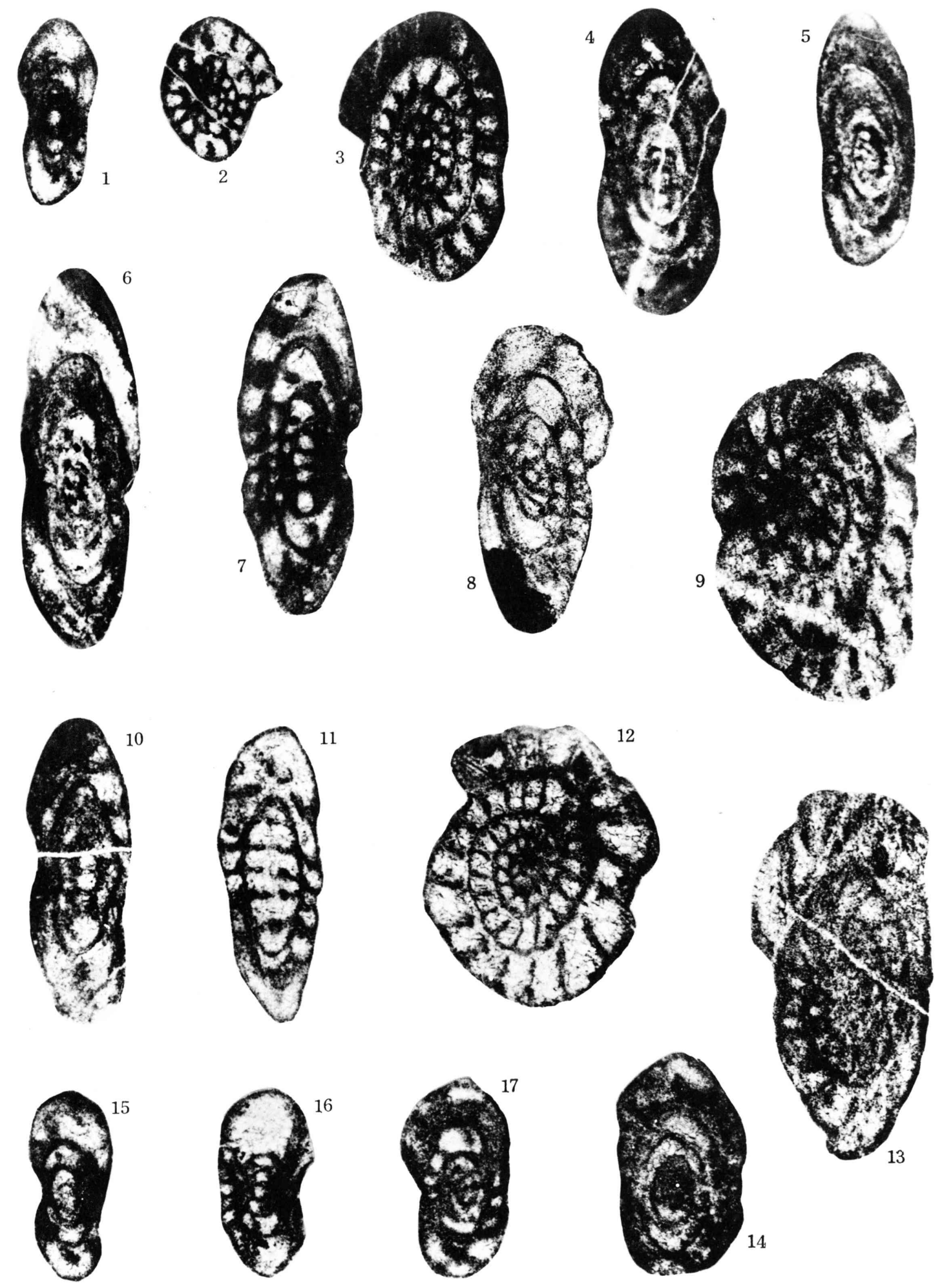